\title{
Antibacterial Activity of Zinc Oxide Nanoparticles in Self- Curing Acrylic Resin Against Streptococcus mutans
}

\author{
Actividad Antibacteriana de Nanopartículas de Óxido de Zinc en \\ Resina Acrílica Autopolimerizable contra Streptococcus mutans
}

\author{
Pía Quezada Morales ${ }^{1}$; Luis Luengo Machuca2; Mario Quezada Aguiluz ${ }^{3,4}$; Manuel Melendrez-Castro5; \\ Helia Bello-Toledo3,4; Gerardo González-Rocha ${ }^{3,4}$ \& Gabriela Sánchez-Sanhueza ${ }^{1,4}$
}

QUEZADA, M. P.; LUENGO, M. L.; QUEZADA, A. M.; MELENDREZ-CASTRO, M.; BELLO-TOLEDO, H.; GONZÁLEZROCHA, G. \& SÁNCHEZ-SANHUEZA, G. Antibacterial activity of zinc oxide nanoparticles in self-curing acrylic resin against Streptococcus mutans. Int. J. Odontostomat., 15(3):694-701, 2021.

\begin{abstract}
Antibacterial activity of zinc oxide nanoparticles in self-curing acrylic resin against Streptococcus mutans. The main objective of this study was to investigate whether nanoparticles of zinc oxide ( $\mathrm{ZnO})$ in self-curing acrylic resin, have antimicrobial properties against Streptococcus mutans, one of the microorganisms involved in the development of caries. Selfcured acrylic resin samples were prepared by incorporating $\mathrm{ZnO}$ nanoparticles at different concentrations based on the minimum inhibitory concentration (MIC) for Streptococcus mutans ATCC 25175. Antibacterial activity against a biofilm was evaluated in samples that were aged in artificial saliva for different times using spectral confocal laser microscopy and scanning electron microscopy. Kruskal-Wallis test using IBM SPSS Statistics version 23.0 software (SPSS Inc. ®, Chicago, IL, United States) were used, establishing the value of $p<0.05$ for statistical significance. The volume of the total biomass that formed in the samples aged for one day was significantly lower than the volume of the total biomass that was formed in those aged for additional days $(p<0.001)$. Electron microscopy analysis revealed high porosity surfaces in all samples. Bacterial clusters were located next to large pores and irregular surfaces, while smooth surfaces had defined and linear organization cocci or simple chains. Considering the limitations of this study, the results suggest that the antibacterial activity of ZnO nanoparticles added to self-curing acrylic (ALIKE) is effective, mainly in fresh 1-day samples, independent of their concentration, and in samples with $16 \mathrm{MIC}$ aged for 14 days, indicating it does not lose its antibacterial activity despite setting for more days. In addition, the ZnO nanoparticles added to ALIKE have the ability to inhibit the formation of biofilms, although they do not minimize the number of viable bacteria.
\end{abstract}

KEY WORDS: Biofilm, Minimum Inhibitory Concentration (MIC). Nanoparticles. Streptococcus mutans. Zinc oxide.

\section{INTRODUCTION}

The creation of a temporary restoration is very important because it is designed to improve aesthetics, to stabilize and to make the dental remnant work for a limited period prior to its replacement by a permanent restoration (Ferro, 2017). Various materials, such as acrylic resins and bis-acryl resins, are used to build them. Acrylic self-curing temporary restoration is widely used due to its efficient functional and aesthetic features and price-quality ratio. Poor execution at this stage can result in microbial contamination of the root canal during endodontic treatment by filtration through mismatches at the sealed edge, as well as periodontal problems, occlusal, joint and aesthetic changes (Sivakumar et al., 2013). Dysbiotic changes in the oral microbiota

\footnotetext{
${ }^{1}$ Departamento de Odontología Restauradora, Facultad de Odontología, Universidad de Concepción, CCP, Chile.

2 Departamento de Prevención y Salud Pública Odontológica, Facultad de Odontología, Universidad de Concepción, CCP, Chile.

${ }^{3}$ Laboratorio de Investigación en Agentes Antibacterianos, Departamento de Microbiología, Facultad de Ciencias Biológicas, Universidad de Concepción, CCP, Chile.

${ }^{4}$ Núcleo Milenio para la Investigación Colaborativa en Resistencia Antimicrobiana - Microb-R, SCL, Chile.

${ }^{5}$ Grupo de Investigación Avanzada de Nanocomposites (GINA), Laboratorio de Materiales Híbridos (HML), Departamento de Ingeniería de Materiales (DIMAT), Facultad de Ingeniería, Universidad de Concepción, Chile.
} 
could cause a tendency to develop lesions in hard tissues, as in cases of dental caries. The mutans group Streptococci (Sakanaka et al., 1989) is remarkable among the identified species that are related to an increased ability to initiate the formation process of carious lesions.

Metallic nanoparticles have various features, including antimicrobial activity against pathogens. Metal oxide nanoparticles, including zinc oxide ( $\mathrm{ZnO})$, produce free radicals, altering the integrity of the bacterial membrane, which leads to the disruption of energy transduction and inhibits respiratory enzymes and DNA synthesis (Zhu et al., 2014). In addition, they are whitish; therefore, they would not interfere with the aesthetics that we could achieve with the acrylic.

The presence of saliva can help reduce dental erosion by diminishing friction of the oral mucosa and lingual surfaces against dental structures (PytkoPolonczyk et al., 2017). Factors such as age, hydration and nutrition of the patient, in addition to ethical problems associated with the use of human saliva for scientific experiments, have allowed us to develop artificial saliva similar to human saliva. Artificial saliva has good acrylic wetting capacity, which would help fulfill the functions of the oral cavity when the tooth has a temporary restoration (Bin Mohsin et al., 2017), but it is unknown if it affects antimicrobial nanoparticle properties. Based on all of the antecedents previously discussed, we aimed to determine whether there is any difference between the conventional technique of making a provisional restoration with different aging times in artificial saliva and the incorporation of $\mathrm{ZnO}$ nanoparticles in terms of their antibacterial action.

\section{MATERIAL AND METHOD}

Preparation of nanoparticle solutions. $\mathrm{ZnO}$ nanoparticles were synthesized and characterized by the Laboratory of Hybrid Materials and Polymers of the Department of Materials Engineering, Faculty of Engineering, through a process called DARC-AC (Medina et al., 2016) (Fig. 1).

Preparation of self-curing acrylic samples with different concentrations of $\mathrm{ZnO}$ nanoparticles at different aging times. For the preparation of the selfcuring acrylic resin (ALIKE GC, Illinois, USA), a mixture was made with 1 liquid part and 3 powder parts by volume. The MIC of the $\mathrm{ZnO}$ nanoparticles against $S$.

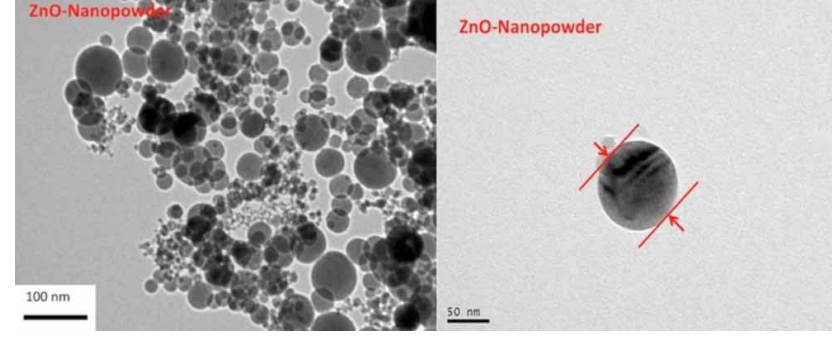

Fig. 1. Zinc oxide nanoparticles obtained by DARC-AC.

mutans ATCC 25175 was $125 \mu \mathrm{g} / \mathrm{mL}$, and the density of ALIKE was $2.56 \mathrm{~g} / \mathrm{mL}$ (according to the manufacturer). These parameters were considered for preparing samples with 8 and 16 (Andrade et al., 2018). Then, 27 cylinders were manufactured in an acetal plate in triplicate for 2 different concentrations of $\mathrm{ZnO}$ nanoparticles and acrylic cylinders without modification as a control per day of aging. The samples were sterilized on each side by UV radiation for $15 \mathrm{~min}$. Afterward, the acrylic resin samples were allowed to age separately in the presence of $1000 \mu \mathrm{L}$ of artificial saliva for 1, 7 and 14 days in 24 -well plates. They were kept in a humid atmosphere at $37^{\circ} \mathrm{C}$, and the artificial saliva was replaced every 3 days.

Preparation of $S$. mutans biofilms on acrylic samples with different percentages of $\mathrm{ZnO}$ nanoparticles. The bacterial strain S. mutans ATCC 25175 (American Type Culture Collection, Manassas, VA, USA) was cultured in liquid Brain Heart Infusion (BHI, Oxoid, Basingstoke, UK) for $24 \mathrm{~h}$ at $37^{\circ} \mathrm{C}$ under aerobic conditions. The standard inoculum of $S$. mutans ATCC 25175 was adjusted by turbidimetry (Fisher Scientific Company, Ottawa, Canada) to a turbidity equivalent to $0.5 \mathrm{McF}$ arland. The acrylic samples were placed in a 24-well plate, and each well was inoculated with a $500 \mu \mathrm{L}$ suspension of $S$. mutans ATCC 25175 to allow the formation of a 7-day biofilm using a modified version of the method described by Botelho et al. (2016).

Analysis. The samples were analyzed by spectral confocal microscopy (LSM 780, ZEISS) and observed under a scanning electron microscope (ETEC Autoscan - SEM) after applying a gold coating by ion bombardment (SPI-Module, Westchester, USA) to determine their viability, the biofilm inhibitory capacity of the test acrylics and the surface structure of the acrylic with and without the addition of nanoparticles. Statistical analyses were performed by the Kruskal-Wallis test using IBM SPSS Statistics version 23.0 software (SPSS Inc. ${ }^{\circledR}$, Chicago, IL, United States), and establishing the value of $p<0.05$ for statistical significance. 


\section{RESULTS}

From the observations under the spectral confocal laser microscope, 3D reflection images were initially obtained from samples aged at 14 days. Multiple porosities can be observed at different depths of the samples, which tended to increase in depth as the MIC increased (Fig. 2). Then, 9 images were obtained, one for each sample (Figure 3: A1-A3, B1-B3, C1-C3).
The software analysis of IMARIS demonstrated that the volume of the total biomass increased in the samples aged in saliva for 7 days compared to samples aged for 1 day, where the most pronounced increase was in samples without $\mathrm{ZnO}$ nanoparticles (Fig. 3 A$B$ ). The total biomass volume in the samples exposed to $16 \mathrm{MIC} \mathrm{ZnO}$ and aged for 14 days showed a significant decrease, reaching the lowest values among all of the samples (Fig. $3 \mathrm{C}$ ).
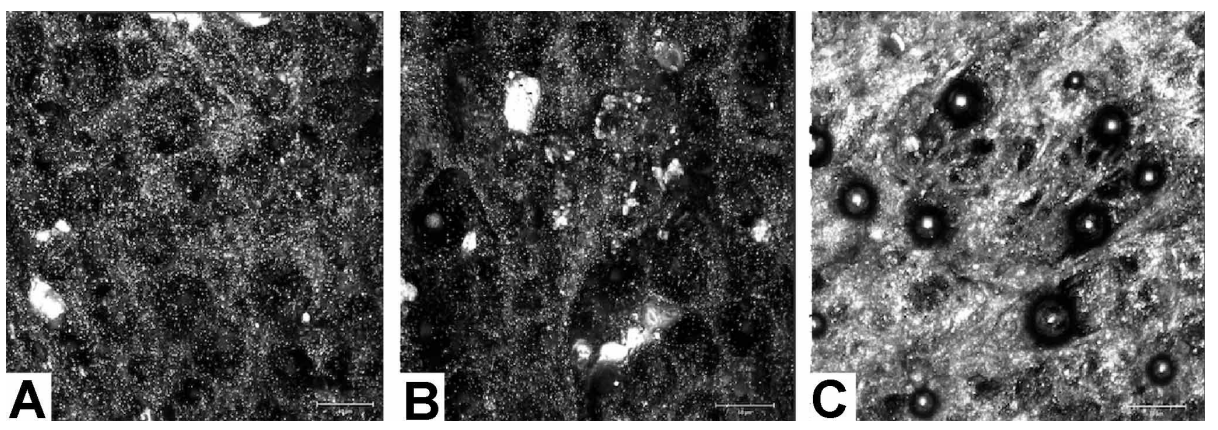

Fig. 2. Reflection of self-curing acrylic samples aged for 14 days, viewed by spectral confocal microscope (25X magnification, $50 \mu \mathrm{m}$ specification bar) (A) without $\mathrm{ZnO}$ nanoparticles (B) 8 MIC of ZnO nanoparticles; (C) 16 MIC of ZnO nanoparticles.
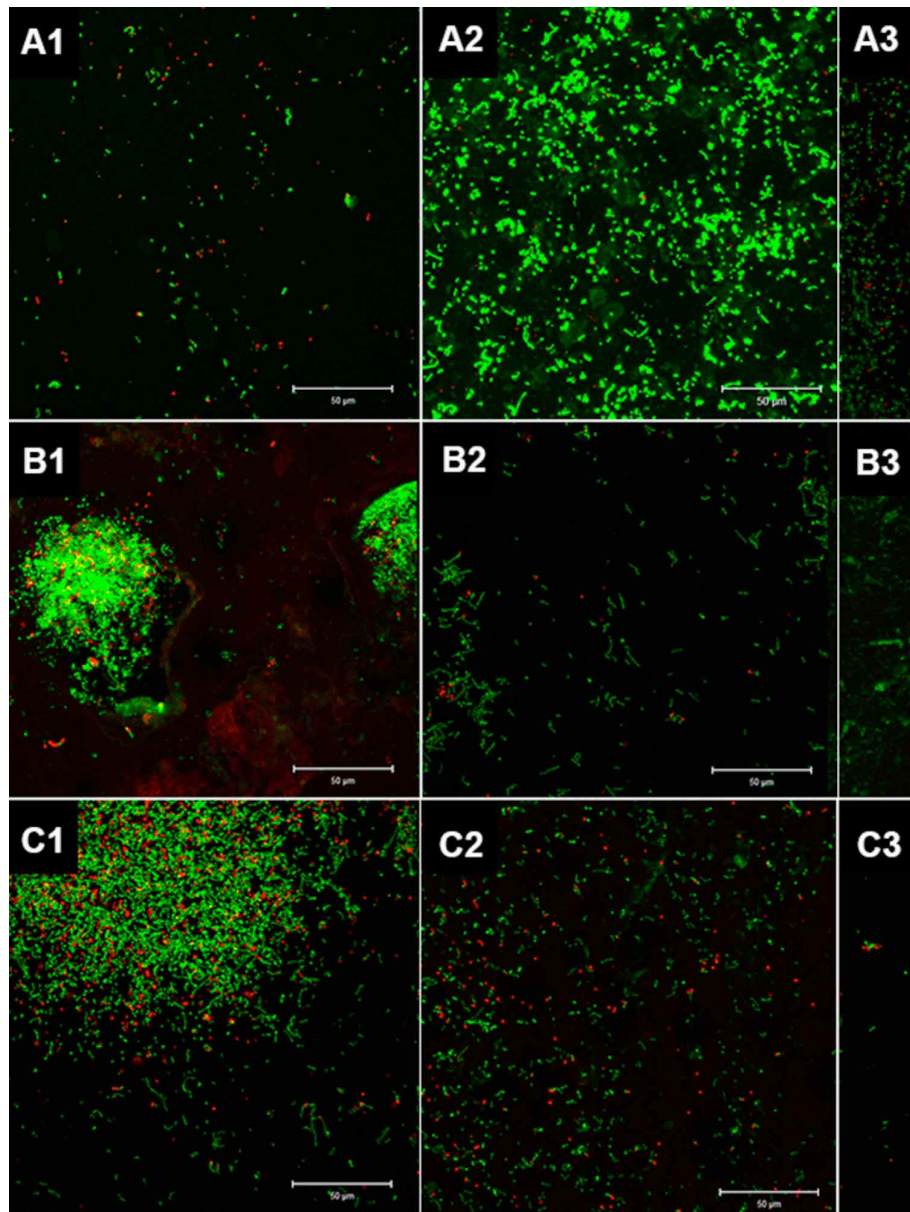

C3

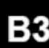

Fig. 3. Self-curing acrylic samples observed by spectral confocal microscopy to evaluate cell viability $(25 \mathrm{X} / 50 \mu \mathrm{m})$. 1 day aged $(\mathrm{A}) ; 7$ days aged $(\mathrm{B}) ; 14$ days aged $(\mathrm{C})$; without $\mathrm{ZnO}$ nanoparticles (1), 8MIC ZnO nanoparticles (2); 16 MIC ZnO nanoparticles (3). 
When comparing the results by days of aging, the largest volume of biomass found could be observed in the sample aged for 7 days without nanoparticles, reaching levels above $140000 \mu \mathrm{m}^{3}$, and the smallest volume of biomass found could be observed in the sample aged for 14 days with 16 MIC, reaching levels below $5000 \mathrm{\mu m}^{3}$. In addition, when comparing the total biomass volume among the different concentrations of nanoparticles, the most significant differences were found, on the one hand, between the samples without nanoparticles, where at 1 day, $11000 \mu \mathrm{m}^{3}$ of the total volume was formed, and on the other hand, at 7 days, when there was an increase in volume reaching 140000 $\mu \mathrm{m}^{3}$ (Fig. 4).
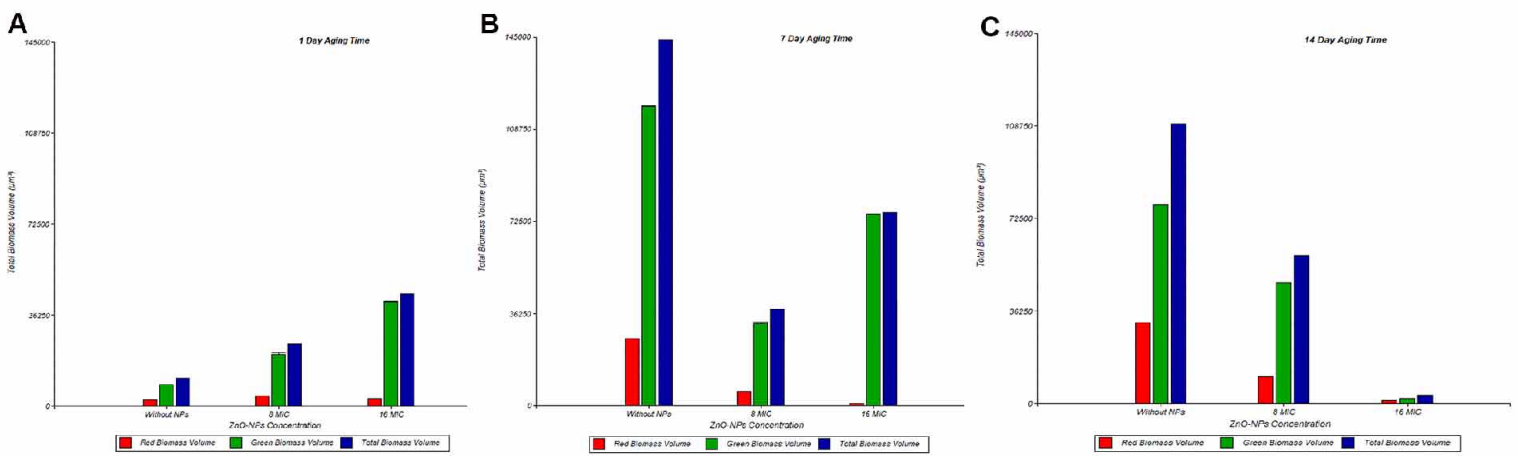

Fig. 4. Viable biomass volume/nonviable biomass volume/total biomass volume in relation to the different MICs at different aging times: 1 day (A), 7 days (B) 14 days (C).
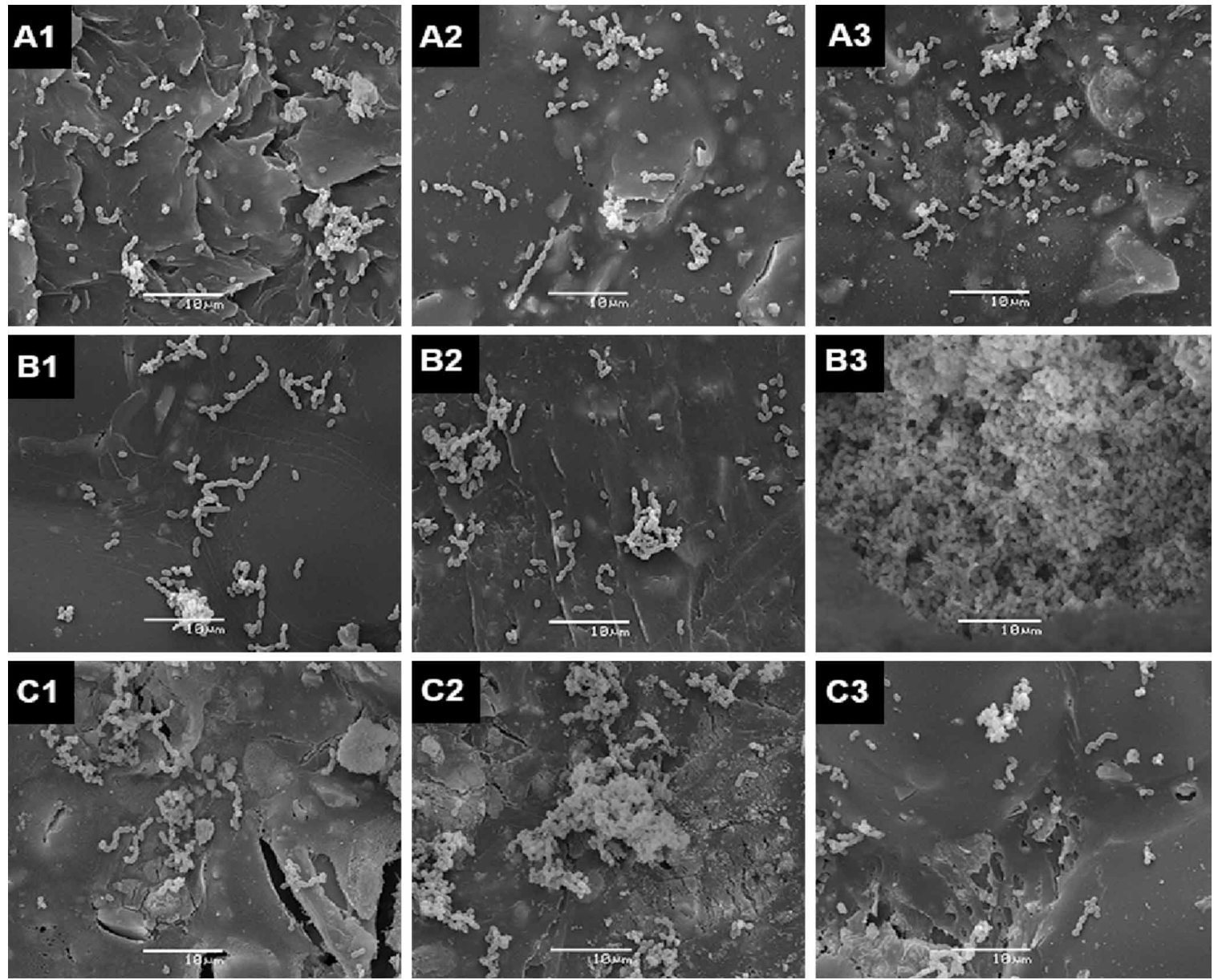

Fig. 5. Self-curing acrylic samples observed by scanning electron microscopy (SEM) (6000X/10 $\mu \mathrm{m}) .1$ day aged (A); 7 days aged (B); 14 days aged (C); without $\mathrm{ZnO}$ nanoparticles (1), 8MIC ZnO nanoparticles (2); 16 MIC ZnO nanoparticles (3). 
In the samples aged for one day, it was observed that in those with $16 \mathrm{MIC}$ of $\mathrm{ZnO}$ nanoparticles, where the volume of viable cells increased in comparison to the other concentrations, significant differences existed in the distribution of the volume of viable biomass. If we compare what happened with the samples aged for 14 days, there are great changes in relation to the 7th day, as a slight increase in the proportion of nonviable was observed, highlighting the samples with $16 \mathrm{MIC}$ where practically no total biomass volume was observed, reaching a minimum value under $1000 \mu \mathrm{m}^{3}$.

The electron microscopy analyses exposed high porosity surfaces in all samples (Fig. 5), where spherical cells organized in long chains and of regular morphology were observed in some images. However, there were also bacterial agglomerations, short chains such as clusters and irregular morphology or scarce bacteria in short chains and varied morphology. The bacterial clusters were mostly located next to large pores and irregular surfaces, whereas smooth surfaces showed cocci of a defined or linear organization or only simple chains.

\section{DISCUSSION}

In this study, the antibacterial activity of increasing concentrations of $\mathrm{ZnO}$ nanoparticles added to self-cured acrylic samples (ALIKE) with different aging times was evaluated under an artificial saliva model on Streptococcus mutans ATCC 25175. In relation to the nanoparticle concentration, it has been reported that light curing composite discs made with the incorporation of $2 \%$ to $5 \% \mathrm{ZnO}$ nanoparticles gives antibacterial properties to the composites against $S$. mutans biofilms, and their physicochemical properties, independent of the vacuoles that are formed, are not altered (Brandão et al., 2018). These results are in agreement with the present study, where 8 and $16 \mathrm{MIC}$ were tested, corresponding to $5 \%, 10 \%$ and $20 \%$ $\mathrm{ZnO}$ nanoparticles.

The observations of the biofilms that were anaerobically grown on the modified composites with $10 \% \mathrm{ZnO}$ nanoparticles show that after 1 day, less biofilm growth was obtained. After 3 days of anaerobic growth, viable cell counts were recorded. The incorporation of $10 \% \mathrm{ZnO}$ nanoparticles did not have significant differences among the composites with and without nanoparticles (Sevinç \& Hanley, 2010), which partially contrasts with our results, since for the unmodified samples with 3 and 7 days of aging, they showed a greater growth of biofilm compared to the samples modified with nanoparticles. In the present study, the total volume of the biomass increased in samples aged in saliva for 7 days as compared to samples aged for 1 day, where the most pronounced and significant increase was in samples without nanoparticles. There was a significant decrease in the samples with 16 MIC aged for 14 days. The significant decrease reached values below $1000 \mu^{3}$, which would support the antibiofilm effect that the nanoparticles had in this sample. A significant antibacterial effect was observed after a $48 \mathrm{~h}$ aging period on composite samples in which $\mathrm{ZnO}$ nanoparticles were incorporated as compared to the control sample. It was noted that the $48 \mathrm{~h}$ group received only one PBS immersion cycle, while the 1-week group received three cycles, as the PBS was updated every 48 hours (Hojati et al., 2013). Unlike in the present investigation, changes were made to the $\mathrm{BHI}$ culture every 24 hours for 5 days.

It is important to mention that it is necessary to incorporate a high percentage of nanoparticles into the acrylic before antibacterial activity is observed, which is corroborated by the previous results where $0.1 \%$ and $0.8 \%$ nanoparticles of $\mathrm{ZnO}, \mathrm{CaO}$ and $\mathrm{TIO} 2$ were incorporated into self-curing acrylic used for making prostheses to see the effect they had on biofilm formation (Anwander et al., 2017). The size and shape of the nanoparticles used did not have the antibacterial activity they were looking for, similar to what was also described by Garcia et al. (2017) where the aging times of the samples and the different MIC were not sufficient to achieve the death of the bacteria.

It has been stated that the particle size should not exceed $100 \mathrm{~nm}$ (Taylor et al., 2013) In the present investigation, the type of particle obtained in the synthesis has a prismatic morphology with an approximate size of $56 \mathrm{~nm}$, which allows a larger contact surface with the bacteria to which they are exposed, which could influence the antibacterial effect of the nanoparticles. This has been corroborated by another report that demonstrated a higher activity for smaller particles than for larger ones; this is due to the high relationship of surface area to volume, which provides a large area for interactions with bacterial cell walls (Ramani et al., 2013). However, in the present study, it cannot be ensured that a proportion of them remained on the surface or in the center of the polymerized mass, or if the polymerization altered the degree of oxidation of the nanoparticles, which could have decreased their antibacterial activity, reflected in 
QUEZADA, M. P.; LUENGO, M. L.; QUEZADA, A. M.; MELENDREZ-CASTRO, M.; BELLO-TOLEDO, H.; GONZÁLEZ-ROCHA, G. \& SÁNCHEZ-SANHUEZA, G. Antibacterial activity of zinc oxide nanoparticles in self-curing acrylic resin against Streptococcus mutans. Int. J. Odontostomat., 15(3):694-701, 2021.

the low volume of nonviable biomass. In this way, the shape of $\mathrm{ZnO}$ nanostructures could influence their internalization mechanism, such as rods and cables that penetrate the cell walls of bacteria more easily than spherical ZnO nanoparticles (Pal et al., 2007). At the same time, Raghupathi et al. (2011) demonstrated that the antibacterial activity of $\mathrm{ZnO}$ nanoparticles on Gram-positive and Gram-negative strains is inversely proportional to the particle size.

In relationship to the antibacterial effect of nanoparticles, it has been demonstrated that they have high activity against bacterial pathogens and low toxicity at low concentrations when added through the deposition/precipitation method. It was verified that resins with the incorporation of $\mathrm{ZnO}$ nanoparticles reduced the bacterial growth by $50 \%$, but when they also incorporated $\mathrm{Ag}$ nanoparticles, the antibacterial effect could reach up to $94 \%$ after 24 hours of incubation (Wang et al., 2017). Kasraei et al. (2014) demonstrated that flow composites to which $1 \% \mathrm{ZnO}$ and Ag nanoparticles were added had a bacteriostatic effect on S. mutans, where the decrease in viable count did not exceed 3 logarithms. It is important to mention that both this work and the others mentioned above used composites modified with nanoparticles, a material that differs in structure and properties from acrylic resins. Moreover, the methodology used was of direct contact with the bacteria followed by counting colonies, which clearly differs from what was done in this study, which evaluated the volume of total biomass formed in addition to its viability and the biofilm inhibitory capacity of the nanoparticles incorporated into the samples. This volume formed in samples aged for one day was significantly lower than the ones formed in samples aged for additional days, which could be directly related to the freshness of the samples where the structure of the nanoparticles is not yet altered and therefore its antibacterial action has not changed and will be performed through various actions such as inhibition by free radical release, membrane disruption, and inactivation of protein interactions, among others (Reddy et al., 2007; Seil \& Webster, 2012).

On the other hand, from the viability analysis in the present study, the samples showed a greater volume of viable bacterial cells compared to nonviable, independent of the concentrations of nanoparticles to which the samples were exposed. This could be because after the formation of the biofilm, the antibacterial action itself did not occur because nanoparticles act by direct contact (Brandão et al.). However, there was evidence of an antibiofilm action in the total biomass formed in the fresh samples and in some concentrations of the samples aged for 14 days.

The saliva variable has been evaluated for the formation of a biofilm for 5 days, where they observed little variation in the viability and thickness of the biofilm throughout the time period, with slight increases and a final nonsignificant decrease; however, they were formed on 3 surfaces without incorporating nanometric structures (Sánchez et al., 2014) In our study, on the first day of aging, the formation of biofilm was 37.6 $\mu \mathrm{m}^{3}$. On the one hand, at 7 days, the predominance of the proportion of living cells over dead cells was highlighted, especially in the control samples, where there were significant differences in the distribution of the volume of the living biomass. On the other hand, at 14 days, neither viable nor nonviable cells were observed in the samples with 16 MIC, so there was practically no biofilm formation.

Vargas-Reus et al. (2012) carried out a study where they demonstrated the efficacy of different nanoparticles (Ag, Ag/CuO composite, $\mathrm{Cu}_{2} \mathrm{O}, \mathrm{CuO}, \mathrm{Ag} /$ $\mathrm{ZnO}$ and $\mathrm{ZnO}$ composite), which acted at concentrations 1000 times less than what an antibiotic needs to make its antibacterial activity work. They demonstrated their activity against the four studied strains, Porphyromonas gingivalis, Fusobacterium nucleatum, Prevotella intermedia and Aggregatibacter actinomycetencomitans. The results produced by the death assay support the broad-spectrum antimicrobial properties of $\mathrm{ZnO}$ nanoparticles.

Interesting concepts have been reported regarding the effectiveness of $\mathrm{ZnO}$ nanoparticles in inhibiting biofilm growth in relation to resins, but they do not mention that some components that are not described by the manufacturers could interfere with the antibacterial mechanism of $\mathrm{ZnO}$ nanoparticles (Brandão et al.). Something similar may have happened in our study, where some of the excipients present in our provisional material, such as methyl methacrylate, stabilized monomer or methanol present in the monomer or liquid could have interfered. Therefore, the manufacturer recommends leaving it for 2 minutes in hot water to eliminate the residual. It has been reported that samples should be left for 7 days in distilled water to decrease the effect of the residual monomer on microbial proliferation (Anwander et al.), which was not considered in this report.

The fewer steps necessary for preparing the material, the lower the number of possible errors at 
the time of mixing, as demonstrated by Hahnel et al. (2019) where slight changes in the filling composition of commercial formulations explain some differences in their handling properties and clinical performance; in our study, to reduce possible risks, the samples were sterilized under UV rays for 30 minutes.

However, one of the most important limitations to consider in these results is the porosity of the acrylic surface and the absence of a polishing step prior to testing. In oral rehabilitation, avoiding dental biofilm adherence is essential to the success of provisional fixed prostheses. If the material and technique are correct, the integrity of the supporting dental tissues will be maintained. It has been found that dental materials with rough surfaces favor bacterial adherence and hinder their elimination by physiological forces (Verran \& Maryan, 1997). This is corroborated by a report that observed polished surfaces with different methods, where they found a lower level of adhered bacteria on polished surfaces compared to those that were not polished or those that were sandblasted; therefore, the roughness of the surface of the provisional crowns depends on the material used, as well as its technique of processing and the polishing type of the surface (Taylor et al., 1998). Another study observed samples obtained from removable prostheses, which were half covered with a light curing glaze and the other half with nothing. They were observed under SEM microscopy after one and three months of use by patients. They demonstrated that the applied glaze did not prevent bacterial colonization, although it helped to facilitate its removal (Sesma et al., 2005). In the present report, the discs were not subjected to a polishing process, which may have resulted in the presence of a rougher, less regular and porous surface, which would allow a larger surface for bacterial adhesion and colonization and alter the antibacterial action of the nanoparticles. When observed by reflection, the images indicate that porosity increases as the MIC increases. It is suggested for future studies to ensure the homogeneous distribution of the nanoparticles through SEM-EDX analysis to assert that the bactericidal effect is truly due to their contact on the surface of the material.

Another limitation of this study is a monospecies model. The single-species model in rehabilitation with $S$. mutans is still accepted, but it should be advanced to multispecies models to get closer to what happens in the oral microbiota (VargasReus et al.).

\section{CONCLUSION}

Considering the limitations of this study, the results suggest that the antibacterial activity of $\mathrm{ZnO}$ nanoparticles added to ALIKE self-curing acrylic is effective, mainly in fresh samples of 1 day of aging, regardless of their concentration, and in samples with $16 \mathrm{MIC}$ aged for 14 days, where it does not lose its antibacterial activity despite having more days of setting. Moreover, $\mathrm{ZnO}$ nanoparticles added to selfcuring acrylic ALIKE have the ability to inhibit the formation of biofilms, although they do not minimize the number of viable bacteria.

QUEZADA, M. P.; LUENGO, M. L.; QUEZADA, A. M.; MELENDREZ-CASTRO, M.; BELLO-TOLEDO, H.; GONZALEZ-ROCHA, G. \& SÁNCHEZ-SANHUEZA, G. ACtividad antibacteriana de nanopartículas de óxido de zinc en resina acrílica autopolimerizable contra Streptococcus mutans. Int. J. Odontostomat., 15(3):694-701, 2021.

RESUMEN: El objetivo principal de este estudio fue investigar si nanopartículas de óxido de zinc ( $\mathrm{ZnO})$, incorporadas a acrílico acrilico de autocurado, tienen propiedades antimicrobianas contra Streptococcus mutans, uno de los microorganismos implicados en el desarrollo de caries. Se prepararon muestras de resina acrílica autopolimerizada mediante la incorporación de nanopartículas de $\mathrm{ZnO}$ a diferentes concentraciones basadas en la concentración mínima inhibitoria (MIC) para Streptococcus mutans ATCC 25175. Se evaluó la actividad antibacteriana contra una biopelícula en muestras envejecidas en saliva artificial para diferentes tiempos utilizando espectros microscopía láser confocal y microscopía electrónica de barrido. Se utilizó la prueba de Kruskal-Wallis utilizando el software IBM SPSS Statistics versión 23.0 (SPSS Inc. $®$, Chicago, IL, Estados Unidos), estableciendo el valor de $p<0,05$ para la significancia estadística. El volumen de la biomasa total que se formó en las muestras envejecidas durante un día fue significativamente menor que el volumen de la biomasa total que se formó en las envejecidas durante días adicionales $(p<0,001)$. El análisis de microscopía electrónica reveló superficies de alta porosidad en todas las muestras. Los cúmulos bacterianos se ubicaron junto a poros grandes y superficies irregulares, mientras que las superficies lisas tenían cocos o cadenas simples de organización lineal y definida. Considerando las limitaciones de este estudio, los resultados sugieren que la actividad antibacteriana de las nanopartículas de $\mathrm{ZnO}$ agregadas al acrílico autopolimerizable (ALIKE) es efectiva, principalmente en muestras frescas de 1 día, independientemente de su concentración, y en muestras con $16 \mathrm{MIC}$ envejecidas para 14 días, lo que indica que no pierde su actividad antibacteriana a pesar de estar fraguada durante más días. Además, las nanopartículas de ZnO añadidas a ALIKE 
QUEZADA, M. P.; LUENGO, M. L.; QUEZADA, A. M.; MELENDREZ-CASTRO, M.; BELLO-TOLEDO, H.; GONZÁLEZ-ROCHA, G. \& SÁNCHEZ-SANHUEZA, G. Antibacterial activity of zinc oxide nanoparticles in self-curing acrylic resin against Streptococcus mutans. Int. J. Odontostomat., 15(3):694-701, 2021.

tienen la capacidad de inhibir la formación de biopelículas, aunque no minimizan el número de bacterias viables.

PALABRAS CLAVES: biofilm, concentración inhibitoria mínima (mic), nanopartículas, Streptococcus mutans, óxido de zinc.

\section{REFERENCES}

Andrade, V.; Martínez, A.; Rojas, N.; Bello-Toledo, H.; Flores, P.; Sánchez-Sanhueza G. \& Catalán, A. Antibacterial activity against Streptococcus mutans and diametrical tensile strength of an interim cement modified with zinc oxide nanoparticles and terpenes: An in vitro study. J. Prosthet. Dent., 119(5):862.e1-862.e7, 2018.

Anwander, M.; Rosentritt, M.; Schneider-Feyrer, S. \& Hahnel, S. Biofilm formation on denture base resin including $\mathrm{ZnO}, \mathrm{CaO}$, and TiO 2 nanoparticles. J. Adv. Prosthodont., 9(6):482-5, 2017.

Bin Mohsin, A. H.; Reddy, V.; Kumar, P.; Raj, J. \& Babu, S. S. Evaluation of wetting ability of five new saliva substitutes on heat-polymerized acrylic resin for retention of complete dentures in dry mouth patients: A comparative study. Pan. Afr. Med. J., 27:185, 2017.

Botelho, J. N.; Villegas-Salinas, M.; Troncoso-Gajardo, P.; Giacaman, R. A. \& Cury, J. A. Enamel and dentine demineralization by a combination of starch and sucrose in a biofilm - caries model. Braz. Oral Res., 30(1):e52, 2016.

Brandão, N. L.; Portela, M. B.; Maia, L. C.; Antônio, A.; Silva, V. L. M. \& da Silva, E. M. Model resin composites incorporating ZnO-NP: activity against S. mutans and physicochemical properties characterization. J. Appl. Oral Sci., 26:e20170270, 2018.

Ferro, K. The Glossary of Prosthodontic Terms: Ninth Edition. J. Prosthet. Dent., 117(5):105, 2017.

Garcia, P. P. N. S.; Cardia, M. F. B.; Francisconi, R. S.; Dovigo, L. N.; Spolidório, D. M. P.; de Souza Rastelli, A. N. \& Botta, A. C. Antibacterial activity of glass ionomer cement modified by zinc oxide nanoparticles. Microsc. Res. Tech., 80(5):456-61, 2017.

Hahnel, S.; Krifka, S.; Behr, M.; Kolbeck, C.; Lang, R. \& Rosentritt, $M$. Performance of resin materials for temporary fixed denture prostheses. J. Oral Sci., 61(2):270-5, 2019.

Hojati, S. T.; Alaghemand, H.; Hamze, F.; Babaki, F. A.; RajabNia, R.; Rezvani, M. B.; Kaviani, M. \& Atai, M. Antibacterial, physical and mechanical properties of flowable resin composites containing zinc oxide nanoparticles. Dent. Mater., 29(5):495-505, 2013.

Kasraei, S.; Sami, L.; Hendi, S.; AliKhani, M. Y.; Rezaei-Soufi, L. \& Khamverdi, Z. Antibacterial properties of composite resins incorporating silver and zinc oxide nanoparticles on Streptococcus mutans and Lactobacillus. Restor. Dent. Endod., 39(2):109-14, 2014.

Medina, M.; Rojas, D.; Flores, P.; Peréz-Tijerina, E. \& Meléndrez, $M$. F. Effect of $\mathrm{ZnO}$ nanoparticles obtained by arc discharge on thermo-mechanical properties of matrix thermoset nanocomposites. J. Appl. Polym. Sci., 133(30):43631, 2016.

Pal, S.; Tak, Y. K. \& Song, J. M. Does the antibacterial activity of silver nanoparticles depend on the shape of the nanoparticle? A study of the Gram-negative bacterium Escherichia coli. Appl. Environ. Microbiol., 73(6):1712-20, 2007.

Pytko-Polonczyk, J. J.; Jakubik, A.; Przeklasa-Bierowiec, A. \& Muszynska. B. Artificial saliva and its use in biological experiments. J. Physiol. Pharmacol., 68(6):807-13, 2017.
Raghupathi, K. R.; Koodali, R. T. \& Manna, A. C. Size-dependent bacterial growth inhibition and mechanism of antibacterial activity of zinc oxide nanoparticles. Langmuir, 27(7):4020-8, 2011.

Ramani, M.; Ponnusamy, S. \& Muthamizhchelvan, C. Preliminary investigations on the antibacterial activity of zinc oxide nanostructures. J. Nanopart. Res., 15(4):1557, 2013.

Reddy, K. M.; Feris, K.; Bell, J.; Wingett, D. G.; Hanley, C. \& Punnoose, A. Selective toxicity of zinc oxide nanoparticles to prokaryotic and eukaryotic systems. Appl. Phys. Lett., 90(213902):213902-1-213902-3, 2007.

Sakanaka, S.; Kim, M.; Taniguchi, M. \& Yamamoto, T. Antibacterial substances in japanese green tea extract against Streptococcus mutans, a cariogenic bacterium. Agric. Biol. Chem., 53(9):230711, 1989.

Sánchez, M. C.; Llama-Palacios, A.; Fernández, E.; Figuero, E.; Marín, M. J.; León, R.; Blanc, V.; Herrera, D. \& Sanz, M. An in vitro biofilm model associated to dental implants: structural and quantitative analysis of in vitro biofilm formation on different dental implant surfaces. Dent. Mater., 30(10):1161-71, 2014.

Seil, J. T. \& Webster, T. J. Antimicrobial applications of nanotechnology: methods and literature. Int. J. Nanomedicine, 7:2767-81, 2012.

Sesma, N.; Laganá, D. C.; Morimoto, S. \& Gil, C. Effect of denture surface glazing on denture plaque formation. Braz. Dent. J., 16(2):129-34, 2005.

Sevinç, B. A. \& Hanley, L. Antibacterial activity of dental composites containing zinc oxide nanoparticles. J. Biomed. Mater. Res. B Appl. Biomater., 94(1):22-31, 2010.

Sivakumar, J. S.; Kumar, B. N. S. \& Shyamala, P. V. Role of provisional restorations in endodontic therapy. J. Pharm. Bioallied Sci., 5(Suppl. 1):S120-4, 2013.

Taylor, R.; Coulombe, S.; Otanicar, T.; Phelan, P.; Gunawan, A.; Lv, W.; Rosengarten, G.; Prasher, R. \& Tyagi, H. Small particles, big impacts: A review of the diverse applications of nanofluids. $J$. Appl. Phys., 113:011301, 2013.

Taylor, R.; Maryan, C. \& Verran, J. Retention of oral microorganisms on cobalt-chromium alloy and dental acrylic resin with different surface finishes. J. Prosthet. Dent., 80(5):592-7, 1998.

Vargas-Reus, M. A.; Memarzadeh, K.; Jie, H.; Ren, G. G. \& Allaker, R. P. Antimicrobial activity of nanoparticulate metal oxides against peri-implantitis pathogens. Int. J. Antimicrob. Agents, 40(2):1359, 2012.

Verran, J. \& Maryan, C. J. Retention of Candida albicans on acrylic resin and silicone of different surface topography. J. Prosthet. Dent., 77(5):535-9, 1997.

Wang, S.; Wu, J.; Yang, H.; Liu, X.; Huang, Q. \& Lu, Z. Antibacterial activity and mechanism of $\mathrm{Ag} / \mathrm{ZnO}$ nanocomposite against anaerobic oral pathogen Streptococcus mutans. J. Mater. Sci. Mater. Med., 28:23, 2017.

Zhu, X.; Radovic-Moreno, A. F.; Wu, J.; Langer. R. \& Shi, J. Nanomedicine in the management of microbial infection Overview and perspectives. Nano Today, 9(4):478-98, 2014

Corresponding author:

Gabriela Sanchez-Sanhueza

Departamento de Odontología Restauradora

Facultad de Odontología

Universidad de Concepción

Roosevelt 1550, box 160-C

Concepción-CHILE

E-mail: gasanchez@udec.cl 